\title{
Evolution of the Human Brain: the key roles of DHA (omega-3 fatty acid) and $\Delta 6$-desaturase gene
}

\author{
Didier Majou* \\ ACTIA, 16, rue Claude Bernard, 75231 Paris cedex 05, France
}

Received 2 August 2017 - Accepted 29 December 2017

\begin{abstract}
The process of hominization involves an increase in brain size. The development of hominids' cognitive capital up to the emergence of Homo sapiens was due to interactive, iterative, and integrative coevolution, allowing positive selection. Although this depends on many factors, in this position paper we show three categories that stand out: gene mutations, food resources, and cognitive and behavioral stimulation. Australopithecus benefited both from the inactivation of the GULO and uricase genes and from bipedalism causing the cognitive capital of the Homo genus to develop advantageously. This evolution depended on two factors. Firstly, a triggering factor: gradual climate change. Homo started to regularly consume meat in addition to plants and insects. Secondly, a stimulating factor: mutations in the FADS 2 gene, which encodes $\Delta 6$-desaturase; a key enzyme for the synthesis of DHA and sapienic acid. The polymorphism of this gene appears to have been essential in allowing the Homo genus to adapt to its food, and for its evolution. It provides an undeniable advantage in terms of the productivity of fat synthesis (DHA), and may partly explain positive selection. With the advent of cooking and new mutations producing even more $F A D S 2$, the brain reached its maximum size in Homo neanderthalensis, in a food ecosystem that provided favorable quantities of $\alpha$-Linolenic acid and DHA. However, the Würm glaciation upset this equilibrium, revealing its fragility as regards to the brain and fertility. Homo sapiens, benefiting from new variants of the FADS2 gene, were able to adapt to this harsh environment, whereas Neanderthal man was unable to do so and became extinct.
\end{abstract}

Keywords: brain / omega-3 / FADS / sapiens / neanderthal

Résumé - Évolution du cerveau de l'homme : les rôles clés du DHA (acide gras oméga-3) et du gène de la $\Delta$ 6-désaturase. Le processus d'hominisation prend en compte notamment l'élargissement du cerveau. Le développement du capital cognitif des hominidés jusqu'à Homo sapiens est le fait d'une coévolution interactive, itérative et intégrative qui a permis une sélection positive. S'il dépend de nombreux facteurs, trois ensembles ressortent: des mutations génétiques, des ressources alimentaires et des stimulations cognitives et comportementales. À partir des australopithèques, qui ont bénéficié de l'inactivation des gènes GULO et uricase, ainsi que de la bipédie, le cerveau du genre Homo a pu avantageusement se développer. Cette évolution dépend de deux facteurs essentiels. Un facteur déclenchant: un changement climatique progressif. Homo est devenu un consommateur régulier de produits carnés en complément des végétaux et d'insectes. Un facteur stimulant: les mutations sur le gène FADS2 de la $\Delta 6$-désaturase, enzyme clé de la synthèse du DHA et de l'acide sapiénique. Le polymorphisme de ce gène apparaît essentiel pour l'adaptation de Homo à son alimentation et pour son évolution. Il confère un indéniable avantage de productivité en synthèse lipidique (DHA) et peut, en partie, expliquer une sélection positive. Avec l'apport de la cuisson et de nouvelles mutations plus productives de FADS2, le volume cérébral a trouvé son apogée chez Homo neanderthalensis dans un écosystème alimentaire favorable en acide $\alpha$-linolénique et DHA. Mais, la glaciation de Würm bouleversa cet équilibre et fit apparaître sa fragilité (cerveau, fertilité). Homo sapiens, avec l'avantage de nouveaux variants du gène FADS2, s'adapta à ce rigoureux environnement, mais l'Homme de Néandertal ne put le faire et disparut.

Mots clés : cerveau / oméga-3 / FADS / sapiens / néanderthal

\footnotetext{
* Correspondence: d.majou@actia-asso.eu
} 


\section{Introduction}

The hominization process consists in the gradual transformation of a line of hominoids into Homo sapiens. The process lasted over 4 million years, beginning when the group of hominoids leading to man separated from the group that led to chimpanzees. This hominization includes all the structural and behavioral changes that led to the characteristics of modern-day humans. The main changes in their habits related to the skillful manufacture and use of tools (predominantly right-handedly), highly elaborate language, and community life reinforced by having domesticated fire. The main morphological changes relate to systematic bipedalism, the anatomy of the hand, the broadening of the hips, and the evolution of the jaw, teeth, and vocal apparatus, as well as an increase in brain size. There are, of course, clear interactions between all these changes. Some of them favor the appearance of others against the backdrop of an ecosystem undergoing long-term change, firstly in Africa (forest, bush and dry savanna with areas of green vegetation running alongside and around rivers and lakes), then in Europe and Asia.

In primates, the increase in brain size and encephalization quotient (the ratio of brain mass to total body mass) (Williams, 2002) are essential characteristics of hominization. These increases began from the Homo genus onwards, approximately 1.9 million years ago. Before this, Australopithecus presented only a modest increase in brain size (on average $400-530 \mathrm{~cm}^{3}$ ) over a period of 2 million years ( 4 to 2 million years ago), with a skull size more or less equivalent to that of large African monkeys or a contemporary newborn baby. With the evolution of the Homo genus, brains grew to $600-700 \mathrm{~cm}^{3}$ for Homo habilis (1.9 to 1.6 million years ago), $800-900 \mathrm{~cm}^{3}$ for the first Homoerectus members (1.8 to 1.5 million years ago), and some $1000 \mathrm{~cm}^{3}$ for the most recent members $(0.5$ to 0.3 million years ago) (Leonard et al., 2010), as Homo erectus tautavelensis $\left(1150 \mathrm{~cm}^{3}\right)$ discovered in the Arago Cave in Tautavel (France) (Lumley and Lumley, 1973). The evolution of Homo erectus is considered to be a major adaptive change in human evolution. The brain also increased considerably in size between 500000 and 30000 years go, albeit with variations: the skull size $\left(1700 \mathrm{~cm}^{3}\right)$ of Neanderthal man was larger than that of Homo sapiens $\left(1500 \mathrm{~cm}^{3}\right)$. The skull size of modern-day man is between 1300 and $1400 \mathrm{~cm}^{3}$ depending on gender; this is slightly smaller than 30000 years ago (Balzeau et al., 2013). In less than 4 million years, brain size has tripled, and is now three times that of primates, whose brain evolution is believed to have lasted 40 million years.

There are many hypotheses that seek to explain the causes of this increase in brain size, combining changes to the ecosystem, pressure from selection, language, socialization, the ability to make tools, artistic talents, domesticating fire, hunting in groups, eating meat and fish, gene mutations, and so on (Jerison, 1973). However, brain size is only a limited indicator of an individual's intellectual capabilities. To date, there are few studies devoted to the evolution of the brain as it relates to physiological evolution, certain gene mutations, and the food resources used in certain key biochemical mechanisms. This evolution over the course of 40 million years was iterative, interactive, and integrative, with an acceleration over a period of 2 million years.

\section{Evolution of skull size and cognitive capital}

Skull size and encephalization quotient are only partial structural indicators of cognitive and memory capacity. Cognitive capacity is formed by neuron-glia networks. Although it is based on anatomical characteristics such as brain size, the number of neurons, and the number of synapses, it also takes into account the spatial organization of the different types of cells and connections, access to the compensatory brain networks that allow tasks to be performed, and the specialization of cells and regions (Majou, 2015). For example, the prefrontal cortex, which is known to have been the last region of the neocortex to develop in terms of both phylogenetics and ontogeny, is one of the regions of the cortex that experienced the greatest expansion over the course of evolution. The zones of lateral convexity of the cortex that developed last are mainly involved in higher executive functions, including those relating to temporal organization of goal-oriented actions in the areas of behavior, cognition, and language (Fuster, 2002). The human brain is not simply a larger version of that of a mammal or even a primate (Bradbury, 2005).

This cognitive capital builds up, develops, and evolves during the course of human life. Thanks to stimulation and learning, these networks become larger, more interconnected, longer, and develop more branches with increased neocortical synapse density (Katzman, 1993), featuring larger cells. There are various theories that attempt to explain this development, the current dominant paradigm being synapse epigenesis. The synaptic plasticity of the cerebral cortex varies throughout an individual's life (Bourgeois, 2005). The different states of neuroplasticity allow neuronal excitability levels to be adjusted: instantaneously (millisecond) and long-term (years); and locally (synapse) or globally (a set of neurons), depending on their stimulation. At any time and for each synapse, a given level of neuronal stimulation corresponds to an appropriate metabolic response mediated by astrocytes. Synapse efficiency depends on the balance between stimulation and response speed. At cellular level, the degree of plasticity or elasticity of reaction is optimized for minimum energy consumption in a metabolic equilibrium or homeostasis, within variable timeframes. The balance between stimulation and energy metabolism, and between synaptic plasticity and metabolic plasticity, depends in particular on individual age-related physiological conditions, genetic predisposition, and diet. This means that neurological activity must be balanced and suited to the metabolism (Majou, 2015).

Thus, it follows that the evolution of cognitive capital must be studied with three interpenetrating fields of investigation: structure (cytoarchitecture); stimulation by behaviors; and the metabolism, subject to powerful evolutionary factors including gene mutations, diet, and ecological changes.

\section{Optimization of energy requirements}

The significant cognitive capital of the Homo genus results in a high nutrient requirement in order to meet its metabolic needs, in particular glucose and oxygen to produce energy in the form of ATP, and antioxidants (L-ascorbic acid, 
glutathione) to inhibit the reactive compounds of oxygen (the superoxide anion $\mathrm{O}_{2}{ }^{\bullet-}$, the hydroxide anion $\mathrm{OH}^{-}$, hydrogen peroxide $\mathrm{H}_{2} \mathrm{O}_{2}$, peroxynitrite $\mathrm{ONOO}^{-}$) produced by oxidative phosphorylation (phosphorylation of ADP into ATP). In relation to its mass ( $2-2.3 \%$ of body weight in adults), the brain uses the largest proportion of the organism's body's total energy requirements. Its resting metabolic rate (RMR) is around $20-23 \%$, whereas that of other primates is some $8-9 \%$ (Mink et al., 1981). The evolution of cognitive capital, therefore, must take into account the brain's considerable energy requirements. This evolution goes hand in hand with the optimization of the energy consumed throughout the body, so as to maximize the intake of glucose in the brain (reduction of consumption in certain organs, targeted increase in intake flow) along with optimization of the homeostasis of antioxidant defenses, according to the FEDOX equilibrium principle (Function-Energy-Anti-Oxidant defenses) (Majou, 2015). It is known that during hominization, total energy use increased substantially from Homo erectus onwards. Total energy used by the latter is $40-45 \%$ higher than that of Australopithecus (Leonard and Robertson, 1997).

\subsection{Cognitive energy metabolism: the key role of the GLUT-1 transporter}

Glucose is an essential substrate for energy metabolism in the brain. It is transported across the blood-brain barrier, from the blood to the brain's interstitial tissue. Extracellular glucose is then transported to the astrocytes (glial cells that take care of the central nervous system, whose role is essential for neurotransmission) and neurons, by means of a facilitated distribution process. This transportation of glucose is mediated by the isoforms of a family of transmembrane glycoproteins known as GLUTs (Joost and Thorens, 2001). GLUT-1 and GLUT-3 are the two isoforms that are extensively expressed in mammal brains.

GLUT-1 is a key factor in the production of ATP and in brain energy modulation, managing the input of glucose from the blood-brain barrier to astrocytes or intercellular space. The GLUT-1 flow controls the overall kinetics of all synapse chemical reactions: neurotransmission, including glutamate neurotransmission (80 to $90 \%$ of synapses are glutamatergic), and cell viability. The key role played by GLUT-1 makes it a limiting factor in energy homeostasis.

\subsection{Mutation of the GULO gene and reinforcement of the role of GLUT-1}

The brain is especially sensitive to oxidative injury because of its high-energy metabolic rate driven by glucose, oxygen, and high levels of polyunsaturated fatty acids that are susceptible to lipid peroxidation (Markesbery, 1999). However, as we shall see later, an omega-3 fatty acid called docosahexaenoic acid (DHA) is a key molecule in the functioning of GLUT-1. The most reactive molecules, such as the hydroxide ion and peroxynitrite, are also capable of oxidizing proteins and nucleic acids. Enzymes involved in energy metabolism depend on oxidative and nitrosative stressors (Brandes et al., 2009). This susceptibility to oxidative modifications also concerns glycogen synthase, an enzyme involved in converting glucose to glycogen (Ernest and Kim, 1974), and glutamine synthetase, an enzyme that plays a major role in the synthesis of glutamine from glutamate captured by the astrocytes (Smith et al., 1991). The process of free radicalmediated protein modification may be a crucial event in the mechanism of neurodegeneration.

As an electron donor, L-ascorbic acid (vitamin C) has an antioxidant function in the brain. During reduction of free radicals, L-ascorbic acid is oxidized to dehydroascorbic acid (DHAA) by giving two electrons. DHAA, is reduced by glutathione, then the oxidized glutathione is reduced by the action of glutathione reductase in a reaction coupled with NADPH. The glutathione/oxidized glutathione redox state is coupled with the L-ascorbic acid/DHAA redox state by both enzymatic and non-enzymatic processes (Harrison and May, 2009). L-ascorbic acid protects cellular components from free radical damage. It scavenges free radicals directly in the aqueous phases of cells and the circulatory system. L-ascorbic acid also protects membrane and other hydrophobic compartments from such damage by regenerating the antioxidant form of vitamin $\mathrm{E}$, which is provided from the diet (Beyer, 1994). Vitamin $\mathrm{E}$ inhibits lipid peroxidation, thus preventing membrane damage and modification of low-density lipoproteins. In particular, partners in defense, vitamin $\mathrm{E}$ and vitamin $\mathrm{C}$, protect vulnerable polyunsaturated fatty acids such as omega-3s.

Whereas most mammals synthesize L-ascorbic acid de novo in their liver, anthropoid primates, including humans, certain bats and guinea pig, are incapable of doing so. This is due to a mutation in the L-gulonolactone oxidase enzyme gene (GULO), thought to have occurred during the late Eocene, approximately 30 to 40 million years ago. These animals have an inactive form of the altered GULO gene (GULO pseudogene) which does not allow the enzyme to be synthesized (Ohta and Nishikimi, 1999). They therefore must obtain it regularly from dietary sources in oxidized form (DHAA), in particular in fruit.

Although the concentration of L-ascorbic acid in the blood is low, the levels in other body fluids, and in intracellular spaces in particular, are comparable to those of other mammals (Johnson et al., 2008). Nerve endings in the brain contain the highest concentrations of L-ascorbic acid in the human body after the suprarenal and pituitary glands (Bourre, 2006). This concentration in the brain exceeds that in blood at least tenfold. However, L-ascorbic acid is not transported across the capillary endothelial cells in the blood-brain barrier. DHAA is transported through the blood-brain barrier by GLUT-1 transporters (Rumsey et al., 1997), and then immediately converted into L-ascorbic acid by enzymes, namely NADPHdependent thioredoxin reductase, glutathione-dependent protein disulfide isomerase, and DHAA reductase (Agus et al., 1997), particularly in the astrocytes. It is interesting to note that the adaptation after the loss of the GULO gene corresponds to the transportation of DHAA by GLUT-1, the glucose transporter; glucose having been the substrate for the synthesis of L-ascorbic acid. Thus, the essential role of GLUT-1 is further reinforced, being the transporter that enables glucose and DHAA to cross the blood-brain barrier. It allows the production of ATP, glutamate (Krebs cycle), and glutathione from glutamate and L-ascorbic acid. These molecules are used in neurotransmission, energy production and the synthesis of 
antioxidants (reduction of free radicals linked to energy production).

GULO is the last enzyme in the metabolic pathway, converting glucose into L-ascorbic acid (Drouin et al., 2011). The deactivation of the GULO gene offers an undeniable energy advantage. For mammals that synthesize L-ascorbic acid, glucose serves as a substrate for at least three synthesis pathways: anaerobic glycolysis, the pentose phosphate pathway (production of NADPH and ribose-5-phosphate), and L-ascorbic acid synthesis. These three pathways are in competition for the same substrate, with all the chemical priority and regulation involved. Indeed, L-ascorbic acid synthesis depends on the concentration of NADPH produced on a competing pathway. This dependent relationship occurs at the expense of L-ascorbic acid, leading to an oxidant situation that limits ATP synthesis. Furthermore, the synthesis requires seven stages, and the action of GULO produces both ascorbic acid and hydrogen peroxide compound; this must be reduced, with a neutral redox balance. The exogenous supply of Lascorbic acid in the diet reduces this competition to two pathways. It increases the efficiency of the glucose, reduces the stages of L-ascorbic acid synthesis, increases responsiveness, and increases cell antioxidant activity. The result offers energy and antioxidant advantages for equal quantities of glucose. The mutation of the GULO gene and a diet high in L-ascorbic acid allowed the development of the primates at the origins of anthropoid primates.

\subsection{Mutation of the uricase gene and reinforcement of antioxidant activities}

Uric acid is a powerful antioxidant. Its plasma concentration in humans (around $300 \mu \mathrm{M}$ ) is considerably higher than the level of L-ascorbic acid (around $50 \mu \mathrm{M}$ ). This makes it one of the major antioxidants in humans. It can react with many oxidants, such as hydrogen peroxide, the hydroxide ion, peroxynitrite, and nitric oxide.

This acid is an intermediary product of purine catabolism (AMP, GMP). It is synthesized from xanthine by the xanthine oxidase enzyme in the liver (Johnson et al., 2008). In almost all mammals, urate oxidase (or uricase) catalyzes the oxidation of uric acid to allantoin (Wu et al., 1989), but in humans and most great apes (chimpanzees, gorillas, and orangutans), the urate oxidase gene is non-functional, such that uric acid is not decomposed (Wu et al., 1989).

This loss of uricase activity occurred progressively from the Eocene onwards and was completed in the early Miocene (around 15-20 million years ago). Three genetic lesions are attributed to pseudogenization of the human uricase gene. A nonsense mutation at codon 33 is common to all great apes (orangutans, gorillas, chimpanzees, and humans) (24 million years ago). Another mutation is located at the splice acceptor site in intron 2 for the chimpanzee and human sequences. An additional nonsense mutation is common for the chimpanzee and human sequences at codon 187 (16 million years ago) (Wu et al., 1992; Kratzer et al., 2014).

Although there is still much speculation about the causes of the evolution of this loss of conversion of urate to allantoin, this mutation was beneficial to great apes and humans. The GULO pseudogene should be placed in correspondence with the uricase pseudogene. The loss of efficiency of these two genes, their physiological consequences, and the similar antioxidant functions of L-ascorbic acid and uric acid establish a correlation between the two events. Indeed, the activity of another antioxidant, superoxide dismutase (SOD) also increased in the species that had lost the ability to synthesize L-ascorbic acid (Nandi et al., 1997). In addition, a high Lascorbic acid intake reduces seric uric acid through a uricosuric effect (Choi et al., 2009). This effect may be due to competition for renal reabsorption via an anion exchange transport system in the tubules (Berger et al., 1977). The mechanistic explanation of the interrelations between urate and L-ascorbic acid show that urate inhibits the oxidation of Lascorbic acid in the blood using iron. L-ascorbic acid reduces ferric iron into ferrous iron by oxidizing into ascorbyl radicals. Protection by urate is provided by the formation of stable complexes with ferric ions, $\mathrm{Fe}^{3+}$-urates, which are ineffective catalysts of the oxidation of L-ascorbic acid; the urate is not oxidized (Davies et al., 1986). In physiological concentrations, urate increases the stability of the concentration of L-ascorbic acid in human blood about fivefold (Sevanian et al., 1985). This protection increases the availability of L-ascorbic acid in the cells and, in particular, in the brain. From anthropoid primates onwards, uricase gene mutations allowed the development of primates leading to the great apes and the Homo genus.

\subsection{Bipedalism and energy saving}

Bipedalism is a determining characteristic of the hominid line. There are a number of theories as to the origin of bipedalism and the factors which triggered it. In any event, the consequence of bipedalism is saved energy when walking to hunt for food, as suggested in a comparative study between human bipedal walking and knuckle walking by chimpanzees. To walk on two legs, humans burn a quarter of the energy required by chimpanzees to walk on four or two limbs (Sockol et al., 2007). The energy cost of locomotion was estimated for Australopithecus afarensis using a model. The results show that they used less energy for walking than other apes in the mid-Pliocene (4 million years ago) (Pontzer et al., 2009). This confirms that energy saving for bipedal locomotion was a major evolution in overall energy optimization. This saving enabled more energy to be supplied to the brain in the form of glucose, without causing a clear increase in skull size.

\subsection{Cooking food}

Cooking food had a decisive impact on chewing and the digestion of proteins, fats, and carbohydrates (Carmody and Wrangham, 2009). This saved energy, resulting in more available calories. Indeed, these two functions use a lot of energy. For meat, which is easy to digest, cooking alters the proteins and facilitates the work of the gastric juices. For plants, especially roots and starchy tubers, it has many different effects. It reduces the energy required to absorb them through gelatinization of the starch and hydrolysis of the fibers (cellulose, lignin), and frees up time and space in the intestines. It thus frees up the glucose not used in digestion for other uses, in particular for the brain. Furthermore, it allows access to 


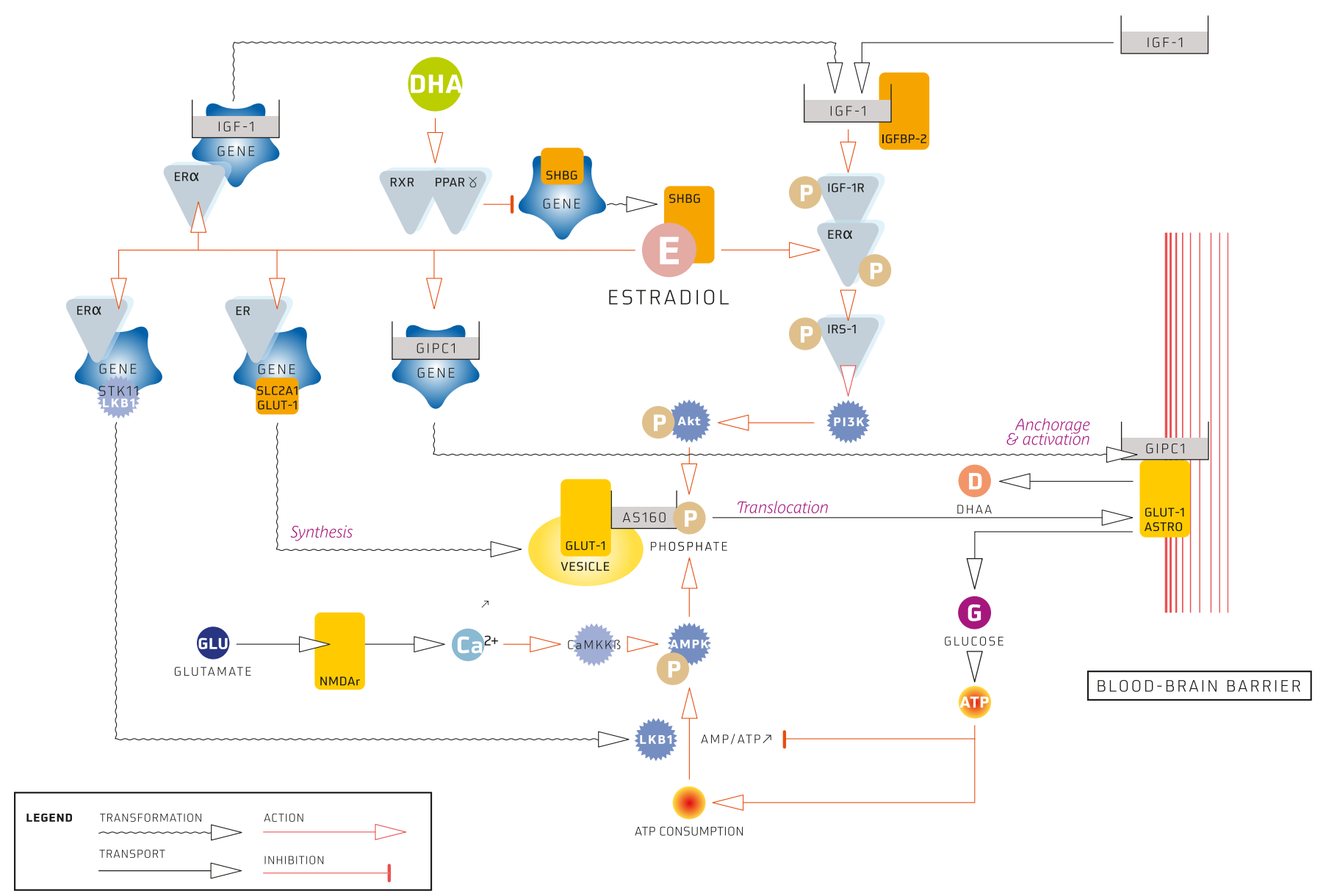

Fig 1. Astrocytes - up-regulation of GLUT-1 by estradiol.

other plants which are not edible raw as they contain antinutritional factors (phytates, tannins, protease inhibitors, etc.) or toxins (alkaloids, etc.), if they are thermolabile. In addition, it facilitates the absorption of certain nutrients, such as non-heme iron from plants. Cooking also plays a role in food preservation and hygiene by destroying parasites, damaging and pathogenic microorganisms, and their toxins.

The impact of cooking is closely linked to the domestication of fire, in a regular, controlled manner. This occurred between 300000 and 400000 years ago (Roebroeks and Villa, 2011), at the time of Neanderthal man. Sites have been found in Europe (Terra Amata near Nice in France, Spy in Belgium, Beeches Pit in England, Schoningen in Germany, and so on) (Lumley, 2006), as well as in Israel (Qesem and Tabun sites) and Iraq (Henry et al., 2011). Homosapiens had also domesticated fire on the southern coast of South Africa 164000 years ago, as evidenced by the site at Pinnacle Point (Brown et al., 2009). Domesticating fire is thus contemporary with the two species of the Homo genus that developed the largest brain sizes. It is clear that cooking is not the cause of this evolution of the brain, as this began with Homo habilis. However, it made a significant contribution to this evolution between the first Homo individuals, and Neanderthal man and Homo sapiens. It enabled certain metabolic and energy barriers to be broken by favoring a higher intake of glucose to the brain, as well as other nutrients, and by assisting other gene mutations which we shall examine later.

\section{DHA as a key regulator of GLUT-1 transporter}

The flow rate of GLUT-1 transporters has a direct impact on the kinetics at synapses and on neurotransmission and cell viability. The free estradiol plays a significant genomic role in the up-regulation of GLUT-1 transporters via estrogen receptors by expression of several genes. However, estradiol is bound to a binding protein called SHBG.The SHBG-bound fraction is not biologically active. DHA blocks transcription of the SHBG gene and increases the amount of free estradiol. We will specify these processes (Fig. 1).

\subsection{Up-regulation by estradiol}

In the brain, 17 $\beta$-estradiol (estradiol) is an estrogen hormone that plays an essential role in the up-regulation of GLUT-1. It increases the number of GLUT-1 molecules on the astrocyte and capillary endothelial cell membranes in contact with the blood-brain barrier. Its intervention takes place in at least three stages (synthesis, transport, and anchoring) to 
increase the flow of glucose and DHAA in response to stimulations (Majou, 2015).

The SLC2A1 gene, which codes for GLUT-1, is an estrogen-regulated gene. It is activated by a transcription factor which also has an estradiol receptor (Wang et al., 2004). In vivo, treatment with estradiol increases GLUT-1 protein concentration in the blood-brain barrier endothelial cells, and GLUT-1 mRNA expression in correlation with the increase of glucose uptake (Shi and Simpkins, 1997). Once synthesized, GLUT-1 protein is stored in vesicles. Estradiol allows the translocation of GLUT-1 vesicles to the cell membranes, favoring the phosphorylation of a vesicle protein (AS160) via the PI3K/AKT signaling pathway or via activation of AMP-activated protein kinase (AMPK) enzyme (Rogers et al., 2009) by the LKB1 enzyme, coded by the STK11 gene. Estradiol also increases the expression of this gene (Mac Innes et al., 2012). Lastly, the GLUT-1 protein is attached to the submembranous actin cytoskeleton by an anchoring protein known as GIPC1 (Reed et al., 2005). Estradiol increases the expression of GIPC1 mRNA (Boverhof et al., 2008).

However, the biologically active fraction of estradiol is its non-protein-bound, free fraction. The role of binding proteins is essential in the modulation of the distribution of active molecules in space and time, and in their protection against lysis. They provide varying flexibility in regulation, depending on the strength of the molecular bond. Low affinity causes rapid action. High affinity allows distribution which is more progressively controlled compared to the "all or nothing" action of synthesis. Albumin and sex hormone-binding globulin (SHBG) modulate the availability of estradiol. Albumin has low affinity and strong capacity for estradiol, contrary to SHBG which has high affinity and low capacity (stable binding constant for albumin: $4.21 \times 10^{4} \mathrm{~L} / \mathrm{mol}$, and for SHBG: $3.14 \times 10^{8} \mathrm{~L} / \mathrm{mol}$ ) (Södergard et al., 1982; Cunningham et al., 1984). All of the above are in a dynamic, competitive equilibrium. The SHBG-bound fraction of estradiol is not biologically active. Thus, the SHBG concentration is decisive for the bioavailability of estradiol and its activity.

\subsection{Bioavailability of estradiol through DHA}

Docosahexaenoic acid (DHA) is an omega-3 polyunsaturated fatty acid (22:6 n-3). It plays a major role in the upregulation of GLUT-1. For example, in primates, DHA levels are proportionate to the local brain metabolic rate for glucose uptake (Brenna and Diau, 2007).

DHA is a major constituent of membrane phospholipids in mammals. Together with other polyunsaturated fatty acids, DHA can modulate their fluidity and the activity of proteins contained by these membranes (enzymes, receptors, transporters, voltage-gated ion channels, etc.). These polyunsaturated fatty acids including DHA can directly affect the activity of membrane proteins like voltage-gated ion channels (Börjesson and Elinder, 2008).

DHA also plays an essential role as a gene transcription modulator via transcription factors, in particular peroxisome proliferator activated receptors (PPARs) and retinoid $\mathrm{X}$ receptors (RXRs). In the form of PPAR-RXR heterodimers, they are activated by their respective ligands that modify their tertiary structures, and enable them to bind to the peroxisome proliferator response element (PPRE) located in the promoter region of target genes. The heterodimer bond on the PPRE activates or inhibits the transcription of the gene. DHA is a preferential ligand in comparison to PPARs and RXRs. The SHBG promoter contains a PPRE. One of the three types of PPAR, PPARy, represses the expression of SHBG in the liver cells, while different PPARy levels and activity contribute directly to the variations in plasma SHBG levels (Selva and Hammond, 2009). By binding to PPARy-RXR, DHA therefore blocks transcription of $\mathrm{SHBG}$, reduces the concentration of SHBG, and increases the quantity of free estradiol. This favors the activity of GLUT-1 and the flow of glucose and DHAA in the Homo genus.

\section{Origin of DHA in the brain}

Mammals are incapable of synthesizing $\alpha$-linolenic acid, the precursor of the omega- 3 polyunsaturated fatty acids, de novo. The supply of DHA to the brain is thought to be governed by a principle of energy optimization. This supply can come from four different, non-exclusive sources, depending on the concentrations of supply and consumption. Two sources are exogenous to the brain, from the blood: (i) directly from the diet in the form of DHA via the blood-brain barrier; (ii) by synthesis in the liver from dietary $\alpha$-linolenic acid (ALA, 18:3 n-3), the essential precursor for DHA, but only 5\% ALA is converted in DHA. Two other sources: (i) from membrane phospholipids that are a major component of all membranes of nerve cells (Jump, 2002) (the enzymes responsible for its release are intracellular phospholipases of the $\mathrm{A}_{2}$ family) (Capper and Marshall 2001); (ii) by synthesis in the astrocytes from dietary ALA via the blood-brain barrier. A more efficient route of incorporation of DHA into brain lipids is via DHA itself, derived from food or phospholipids or by metabolism in liver, rather than by metabolism from ALA in astrocytes (Sinclair and Crawford, 1972).

The synthesis pathway of DHA is known as Sprecher's shunt. From ALA found in the diet, a series of enzyme transformations including two desaturases $(\Delta 6$-desaturase and $\Delta 5$-desaturase) and elongases in the endoplasmic reticulum, followed by a peroxisomal $\beta$-oxydation, results in DHA (Voss et al., 1991. $\Delta 6$-desaturase catalyzes two essential stages of DHA biosynthesis (Cho et al., 1999; Stoffel et al., 2008). As the second stage of desaturation by this enzyme is limiting, it makes $\Delta 6$-desaturase a key enzyme in DHA synthesis (Lattka et al., 2010; Tosi et al., 2014; O’Neill and Minihane, 2017; Delplanque, 2017).

The rate of DHA produced is directly linked to the level of $\Delta 6$-desaturase available, but also to the ALA content. The ratio of omega-3/omega-6 fatty acids is also important for an efficient conversion. However, at that time, this ratio (approximately 1) was very favorable (Simopoulos, 2006). Non-converted ALA undergoes aerobic $\beta$-oxidation in the astrocyte mitochondrion (Edmond et al., 1987) and is fully degraded into acetyl-CoA (Lynen's helix). The latter occurs in several synthesis pathways, including the production of ATP (Krebs cycle and the respiratory chain), lipogenesis, and cholesterogenesis (mevalonate pathway), resulting in steroid hormones, including estradiol. 
The $\Delta 6$-desaturase gene, a FADS2 gene (Fatty Acid Desaturase 2), is expressed in particular in the liver, heart, brain (astrocytes) (Innis and Dyer, 2002; Nakamura and Nara, 2004), adipocytes, and sebaceous glands (Ge et al., 2003). The PPAR $\alpha$-RXR $\alpha$ heterodimer modulates the transcription of the FADS2 gene (Tang et al., 2003; Majou, 2015). The expression of $\Delta 6$-desaturase is retro-inhibited by intracellular free DHA (Matsuzaka et al., 2002; Majou, 2015).

The DHA requirements of modern humans are estimated at around $250 \mathrm{mg}$ per day, based on cardiovascular considerations (EFSA, 2010) for a brain size of $1300-1400 \mathrm{~cm}^{3}$. All other things being equal, with the same neuron activity, and extrapolating arithmetically from the brain size of Paleolithic man, daily DHA requirements would be $110 \mathrm{mg}$ for Homo habilis, $160 \mathrm{mg}$ for Homo erectus, $275 \mathrm{mg}$ for Homo sapiens, and $310 \mathrm{mg}$ for Homo neanderthalensis.

\section{DHA: Polymorphism of the $\Delta 6$-desaturase gene and consequences for the evolution of the brain}

Although food-based DHA plays a direct role on its plasma and erythrocytic levels, genetic factors have an important role in influencing the DHA concentration in human tissue through an ALA-rich diet. The FADS1 and FADS2 genes, which code $\Delta 5$-desaturase and $\Delta 6$-desaturase respectively, form a group of genes with FADS3 on human chromosome 11 (11q12-Q13.1) (Nakamura and Nara, 2004). In the NCBI SNP database, more than 3285 simple nucleotidic polymorphisms (SNPs) are referenced on FADS2 for Homo sapiens.

Although the first studies on FADS gene polymorphisms are recent (Schaeffer et al., 2006), several significant associations have been confirmed between FADS genotypes and long-chain polyunsaturated fatty acids, in diverse types of human tissue (erythrocytes, plasma, skin, breast milk, etc.) showing that the polymorphisms on the FADS gene cluster are major regulators of the synthesis of this type of fatty acid. Several studies have shown a close correlation between several SNPs in the FADS1 and FADS2 genes and the concentration of omega-3 and -6 fatty acids. (Schaeffer et al., 2006; Xie and Innis, 2008; Rzehak et al., 2009; Glaser et al., 2011). Homozygous carriers of different minor alleles have higher desaturase substrates ( $\alpha$-linolenic acid, linoleic acid) and lower levels of desaturation products (DHA, EPA, arachidonic acid) (Glaser et al., 2011). This suggests a reduced expression of desaturases in the case of these polymorphisms (MoltóPuigmarti et al., 2010). For example, polymorphism rs 968567 has a strong influence on DHA synthesis and the regulation of the transcription of FADS2.

One study (Ameur et al., 2012) concerned the genotyping of the FADS cluster of five European cohorts, as well as the genomic data available from human populations, archaic hominids, and more distant primates. The results show that modern humans have two haplotypes (groups of alleles with different loci located on the same chromosome) - A and D - for the FADS cluster defined by 28 SNPs. These two haplotypes differ considerably in their capacity to synthesize long-chain fatty acids. In the two families of fatty acids - omega- 3 and omega-6 - haplotype D is strongly associated with lower levels of precursors in the synthesis of fatty acids $(\alpha$-linolenic acid, linoleic acid) and higher levels of EPA, DHA, and arachidonic acid. This indicates that this haplotype is more effective in converting precursors. People who are homozygous for haplotype D have $24 \%$ more DHA and $43 \%$ higher levels of arachidonic acid than homozygotes for haplotype A. The geographical distribution of haplotypes $\mathrm{A}$ and $\mathrm{D}$ differ considerably between continents. In African populations, haplotype $\mathrm{A}$ is practically absent (1\% of chromosomes), whereas in southern and western Europe, South-East Asia and Oceania, it is present in $25-50 \%$ of people. The data on Neanderthal man, based on the incomplete sequences of three individuals (Green et al., 2010), show nucleotidic variants found on the two human haplotypes, but on the whole they are more similar for haplotype A. Haplotype D appeared on the evolutionary line leading to modern humans, well after the split between humans' and chimpanzees' common ancestor. Based on the number of SNPs that accumulated between the DD genotypes, haplotype D is estimated to have appeared before Homo sapiens and dates to between 210000 and 300 000 years ago-before the migration from Africa (around 80000 years ago), but after the appearance of the oldest preNeanderthals in Europe (around 500000 years ago). Likewise, based on the variability between AA genotypes, haplotype A is estimated to date back at least 600000 years (Ameur et al., 2012), to the period of Homo erectus.

\section{A genetic evolution of the FADS2 gene starting with the Homo genus}

Two events, which took place during the same period, could indicate that the consequences of the genetic mutations of the FADS2 gene in terms of the synthesis of $\Delta 6$-desaturase were revealed well before haplotype A, as defined in the study cited. These events were the progressive development of the brain and the disappearance of fur, starting with Homo habilis around 1.9 million years ago, and continuing with Homo erectus.

Even though the causes of this disappearance remain hypothetical, hunter-gatherers needed high levels of endurance to move around in the hot savanna (Porter, 2001). They had to be able to resist dehydration and thermoregulate their bodies (Porter, 1993). Sweat humidifies the surface of the skin and hairs, which lowers the body temperature thanks to evaporation. Secreted by sudoriparous exocrine glands, it is composed of $99 \%$ water, as well as electrolytes (sodium chloride, potassium ions, calcium, and magnesium) and organic acids (lactic, acetic, propionic, butyric, and uric acid). But sweat must remain on the skin's surface to be effective. This was enabled by morphological adaptations, as well as the lowering of sweat's surface tension, allowing it to form a coating rather than droplets. The sebum of sebaceous glands will play this role of surface active agent and lubricant. More generally, it forms a protective hydrolipidic film that covers the entire human epidermis. This emulsion protects the skin from drying and fights microbial attacks. In humans, it is principally composed of triglycerides, wax esters, free fatty acids, and squalene (Picardo et al., 2009). This composition varies between species and this difference is due to the specific functions that the sebum plays for the given species (Picardo et al., 2009). Human sebum contains more free fatty acids than 
that of other mammals, and the most abundant monounsaturated fatty acid is sapienic acid (16:1 n-10). This fatty acid has an extremely rare double bond, located between carbons 6 and 7 of the carboxyl terminal. Sapienic acid is completely unique to the human race, hence its name. It is synthetized by the desaturation of palmitic acid (16:0). This desaturation is catalyzed by $\Delta 6$-desaturase (Ge et al., 2003). It has both a strong bactericidal effect (Drake et al., 2008; Prouty and Pappas, 2015) and, indirectly, protects the keratinocytes' barrier function (epidermis) by competing with the synthesis of oleic acid from palmitic acid in skin cells. An increased concentration of oleic acid causes better absorption of calcium by cells by disturbing the barrier function's homeostasis (Katsuta et al., 2005). Thus, as with increased brain size, only a significant increase in $\Delta 6$-desaturase concentration allowed the disappearance of fur. This means increased productivity of the FADS2 gene and/or reduced inhibition, through nucleotidic mutations on this gene.

\section{Interactive and iterative coevolution between genetic mutations, diet, and the stimulation of cognitive capacities}

For the Homo genus, starting with the ancestors of the Australopithecus genus, the beginning of a virtuous cycle that leads to the development of the brain and cognitive capital became possible. It developed through an interactive, iterative, and multifactorial coevolution, between various elements.

The cognitive capacities of each individual were subjected to growing behavioral stimulation with increasing complexity, which required physiological solutions (energy, antioxidants, etc.). Their development gradually led to new technologies (stone tools, weapons) and social innovations (imitation, education, the notion of groups).

Genetic mutations on the FADS2 gene in particular reduced its susceptibility to retro-inhibition by DHA. This both increased the efficiency of the conversion of ALA into DHA and increased the rate of plasma DHA through exogenous DHA supply (meat, seafood) with no deleterious effect on its endogenous synthesis. The polymorphism of the FADS2 gene is a stimulating factor in the brain's quantitative and qualitative evolution.

\subsection{Climate: a factor that triggered dietary changes}

At the crossroads of physiological expectations and genetic mutations, a diet with higher energy and nutritional intake is vital for positive selection. Indeed, this evolution of brain volume and activity required more and more glucose and Lascorbic acid in particular, and therefore more GLUT-1 and DHA, produced according to the mechanisms described above. Gradual climate change, with major repercussions on the subtropical African ecosystem, was the factor that triggered dietary changes. The climate appears to have become cooler and more arid around 2.8 million years ago, with peaks at around 1.7 million years ago and 1 million years ago (Menocal, 2004).

These first changes affected Australopithecus with the change from humid tropical forests and plains to wooded savanna. Their diet was essentially vegetarian and composed of fruit (source of L-ascorbic acid and $\beta$-carotene in particular), sprouts (proteins), soft leaves, buds, flowers, herbaceous plants (rich in ALA) (Reiner et al., 2014), honey, and eggs, depending on the season (dry or wet). It was an omnivorous diet since it was occasionally complemented by small animals (rodents, birds, reptiles, and invertebrates). The nutritional quality of certain insects, their nymphs, and their larvae is also worth noting. Some species in particular are rich in ALA, like lepidoptera (Bombycidae, Saturniidae, and Noctuidae families) and orthoptera (Acrididae family) (Defoliart, 1991; Womeni et al., 2009). Imbrasia caterpillars, for example, or crickets contain $10 \%$ of ALA on dry matter. This diet was close to that of chimpanzees, except that Australopithecus knew how to unearth roots, tubers, onions, bulbs, and rhizomes, probably using digging sticks. The inclusion of these underground reserves of nutrition in their diet probably reduced their fiber intake and increased their starch and carbohydrate intake (Conklin-Brittain et al., 1998). Australopithecus's "megadont" (powerful tooth for chewing) enabled it to eat this type of tough food, as well as the parts that were protected from desiccation (nuts and seeds, etc.) (Kay, 1985).

Following this climate change and its effects on vegetation, plant-based food of good nutritional quality, and fruit in particular, became more difficult to obtain (major seasonal variations, local dispersion, and less diversity). Moreover, foraging for sufficient food and water required greater expenditure of energy (Milton, 2003) whereas Australopithecus had a thick coat of hair, which was problematic for perspiration and body cooling. Meat was the most regular source of high quality nutrition, for those able to exploit it.

\subsection{Homo genus is better adapted}

The members of the Homo genus underwent morphological changes that allowed them to adapt to these new sources of food and use them to their benefit. Positive mutations on the $F A D S 2$ gene, in particular, led to an increase in skull size as well as the loss of body hair, which facilitated their movement. This resulted in the production of the first stone tools (Plummer, 2004), which had a decisive role in the regular consumption of meat and the evolution of the genus.

As well as eating small prey, Homo habilis, which had no hunting ability or weapons, had access to large African herbivores, killed by accident, disease or predators, by scavenging carcasses (Blumenschine and Cavallo, 1992). However, this practice put them in uneven competition with the great carnivores (lions and leopards) and carrion feeders (hyenas) for the edible parts. They had to make with the less noble parts, like the bones and the skulls (Blumenschine, 1986). Thanks to stone tools capable of breaking and cutting (choppers, hammers), the brain and the bone marrow were the most easily available parts for these prehistoric scavengers. When possible, they also recovered meat and sub-cutaneous fat. However, in the African climate, this supply was erratic and subject to rapid microbial and oxidative deterioration (Guil-Guerrero et al., 2013) from pathogenic or spoiling bacteria. Homoerectus, with its more elaborate tools and probably techniques for capturing prey, and then hunting, and 
better organization, was able to obtain entire fresh carcasses. Butchery practices are recorded from around 1.5 million years ago, with disarticulation and carving up of meat and fat and extraction of the bone marrow (Pobiner et al., 2008).

Meat provides all the amino acids necessary for the synthesis of human proteins, as well as many minerals, heme iron, and vitamins A, B1, B3, B6, B9, B12, and K. Moreover, bone marrow $(488 \mathrm{kcal} / 100 \mathrm{~g})$ and sub-cutaneous fat $(745 \mathrm{kcal} /$ $100 \mathrm{~g}$ ) have high concentrations of energy (Cordain et al., 2001). Animal proteins are more bioavailable that those of plants (Carpenter, 1994). This means that Hominins did not need to eat as much meat as plants to satisfy its protein requirements. It freed up time and space in the gut for energyrich plants like fruit, starchy products, nuts and seeds.

In terms of intestinal anatomy and digestive kinetics, meat consumption did not pose a problem. However, protein-rich diets can exceed the liver's capacity to convert the excess nitrogen into urea. Excessive protein intake becomes dangerous when the percentage of calories from protein exceeds $35 \%$ of the total diet $(3 \mathrm{~g} / \mathrm{kg}$ of body weight/day). This toxicity notably takes the form of hyperaminoacidemia, hyperammoniemia, and hyperinsulinemia leading to death (Bilsborough and Mann, 2006). This means the non-deleterious protein intake for adult Homo habilis was around $135 \mathrm{~g} /$ day, for Homo erectus it was around $180 \mathrm{~g} / \mathrm{day}$, Homo sapiens $210 \mathrm{~g} / \mathrm{day}$, and Homo neanderthalensis $240 \mathrm{~g} /$ day. With a ratio of around $22.7 \mathrm{~g}$ proteins $/ 100 \mathrm{~g}$ of muscle for African ruminants (Cordain et al., 2001), this was a maximum muscle intake around $600 \mathrm{~g}, 800 \mathrm{~g}$ and $925 \mathrm{~g}$ respectively for adults. The consumption of subcutaneous fat made it possible to avoid excess protein intake. The brains of African herbivores provided decent quantities of DHA depending on the species, making an average of $860 \mathrm{mg} /$ $100 \mathrm{~g}$, and much less for the liver $(40 \mathrm{mg} / 100 \mathrm{~g})$ and muscles $(10 \mathrm{mg} / 100 \mathrm{~g})$ (Cordain et al., 2001). The fatty tissue of nonruminant herbivores is high in ALA. For the zebra (Equus burchelli), which was widely consumed, it can reach $47.5 \%$ of total lipids (Williams and Crawford, 1987). However, this ALA content is completely dependent on the type of plants grazed.

In combination with Australopithecus's omnivorous diet, the mutation of the FADS2 gene and the help of the first tools, the members of the Homo genus progressively benefited from the nutritional advantages of meat products. Homo habilis benefited from the DHA in the brains of carrion and the energy of their bone marrow, meeting the metabolic needs of its larger brain. With the same factors, Homo erectus and Homo sapiens also drew benefits from the DHA in other parts of the carcasses of African herbivores, including the muscle and liver, making up 80 to $100 \mathrm{mg}$ of the daily protein ration, as well as the ALA in fatty tissue. The transformation of ALA into DHA benefited from the polymorphism of FADS2. This more regular, additional intake met the metabolic needs for energy, antioxidants, and DHA caused by new stimulations. With these physiological, technical (tools, weapons, hunting, etc.) and social advances over its predecessors, as well as likely genetic mutations on FADS2 with positive effects, a new species progressively emerged in Africa, around 200000 years ago; Homo sapiens. Its body size as well as its cognitive capacity and brain size had increased considerably, reaching $1500 \mathrm{~cm}^{3}$. The productivity of new FADS2 variants was able to meet its requirements. For some of them, in particularly specific environmental niches (lakes, rivers, and coastlines)
(Walter et al., 2000), and aquatic products (contemporary examples would include the Nile perch, the Nile tilapia, tilapia zillii, and sardines) (Robert et al., 2014), which have much higher levels of DHA than herbivores muscles, must have been beneficial to their evolution (Broadhurst et al., 1998, 2002; Kuipers et al., 2010).

DHA is essential for humans from weaning to adult age, as well as at perinatal stage. Indeed, the brain of a newborn baby consumes around $74 \%$ of the energy absorbed by the body (Holliday, 1971). As we will see later, breast milk provides DHA throughout the first year. The amount of this fatty acid that it contains depends on the mother's diet (Brenna et al., 2007). In the breast milk following vegan, vegetarian, and omnivorous diets, the DHA content is respectively $0.14 \%$, $0.3 \%$ and $0.37 \%$ of total lipids (Sanders and Reddy, 1992).

The additional regular intake of meat, and maybe aquatic products too, was decisive in the emergence of the Homo genus (Leonard and Robertson, 1994), as well as the cerebral development of its first members. This concurrent evolution of the brain and cognitive capital is the result of one stimulating factor in particular: the positive polymorphism of the FADS2 gene, and a triggering factor in dietary changes: progressive climate change, which had a major impact on the subtropical African ecosystem.

\section{The polymorphism of the FADS2 gene: an aggravating factor in the disappearance of Homo neanderthalensis?}

\subsection{Homo neanderthalensis in a favorable ecosystem}

Homo erectus died out, but in the meantime, other species of hunter-gatherers appeared. One of these was Homo neanderthalensis, around 300 to 400000 years ago, in Europe, which showed a significant evolution in brain size. Its average skull size was between 1500 and $1600 \mathrm{~cm}^{3}$, with some individuals having skulls measuring $1700 \mathrm{~cm}^{3}$. Neanderthal man had the biggest brain of all hominin species up to the current day. But it had a strong similarity in the haplotype of the least DHA-productive FADS cluster (Green et al., 2010) This situation - a large skull size with low DHA productivitycreated a delicate equilibrium. A diet with sufficient quantities of DHA and/or ALA to meet its physiological neurological needs, allowed this species to evolve and thrive for tens of thousands of years. A favorable ecosystem for this type of diet existed during the Riss-Würm interglacial period (the Eemien period, 130000 to 115000 years ago) (Dahl-Jensen et al., 2013), which was warmer and more humid than currently. Hippopotamuses could be found as far north as the Rhine and the Thames (Van Kolfschoten, 2000), with forests reaching up to North Cape, well within the Arctic circle, which is now covered with tundra. Leafy trees like the oak and the hazelnut tree, were found as far north as Oulu in Finland $(150 \mathrm{~km}$ south of the Arctic circle). The sea level was probably 6 to $9 \mathrm{~m}$ higher than currently (Dutton and Lambeck, 2012). The last ice age in the Alpine region, called the Würm glaciation, started around 115000 years ago, with a long interstadial period, until around 70000 years ago. Temperatures were still relatively high, but fell more and more. The climate was still humid. In the South of the Alps, the fauna was similar to that of temperate regions 
(deer, brown beers, boar, wolves, cave lions, weasels, etc.). Neanderthal man was able to find a lipid-based diet that suited its polymorphism during this interstadial period, coupled with carbohydrates from roots, tubers, etc. (Hardy, 2010).

\subsection{Homo neanderthalensis and Homo sapiens in a degraded ecosystem}

A first cooling period took place around 50 to 70000 years ago. The climate became progressively drier, the forest disappeared slowly, making way for steppes with small trees. Following another interstadial period, less harsh than the midWürm period (30 to 50000 years ago), the cold and drought reached their peak at 10 to 30000 years ago. In the area covered by modern-day France, there were zones of tundra, frozen soil (permafrost) and steppes (Bocquet-Appel et al., 2005; Demars, 2008). During this period, the average annual temperatures in the Alps were 10 to $12^{\circ} \mathrm{C}$ lower than today. Cold climate fauna lived north of the Pyrenees and the Alps, with mainly reindeer and, less frequently, mammoths, bison, and horses (Equus gracilis). The sub-cutaneous fat of monogastric mammals (horses and mammoths) provided large quantities of ALA (around 20\% of total fatty acids) (Guil-Guerrero et al., 2013; Guil-Guerrero et al., 2014). This ALA content is also completely dependent on the plants grazed, in particular omega-3 rich lichen (Sampels, 2005). In more temperate Mediterranean Europe, where deer, ibex, chamois, boar and cows thrived, the diet was mostly meat-based with protein and fat intake, and not much plant picking, although they consumed starch-rich roots and tubers (Hardy, 2010).

Neanderthal man, and Homosapiens who arrived in Europe about 40000 years ago, apparently experienced differently the degradation of their ecosystem. The former went extinct while the latter adapted.

With its large skull size and genetic polymorphism on the FADS cluster (haplotype A), Neanderthal man was highly dependent on DHA and carbohydrates in its diet. During this ice age, consumption of these nutrients decreased significantly, creating an imbalance in the efficiency of relations between skull size, cognitive capital, and neuronal metabolism. On the one hand, carbohydrates were obtained from starch-rich roots and tubers, whose consumption was facilitated by cooking them. The hydrolysis of starch begins during chewing, thanks to an enzyme in saliva: salivary amylase. This enzyme is coded by the $A M Y 1$ gene. But like chimpanzees, Neanderthal man only had two copies (diploidy) of this gene. Homo sapiens, on the other hand, carries six copies. This difference is directly correlated with the concentration of salivary proteins, as well as how easy it is to break down starch (Perry et al., 2007) (Perry et al., 2015), and the kinetics of glucose bioavailability. Moreover, as early as the perinatal stage, dyslipidemia in the mother, based on genetics and diet, is passed on to the child in two ways; genetics and the diet of the fetus (via the placenta) and new-born babies (breast milk) (Moltó-Puigmarti et al., 2010). Indeed, the DHA concentration of maternal milk is closely linked to the concentration of ALA and DHA in the mother's diet (Makrides et al., 1996). Yet the perinatal stage is the period when most DHA is accumulated in children (Wainwright, 1992). Moreover, newborn humans are "premature" compared to other mammals. There are two reasons for this: the upright position of bipeds required narrower hips in women, whereas skull size increased. The quantity of DHA accumulated specifically in the brain during the first six months of life reaches around $1 \mathrm{~g}$, nearly $50 \%$ of the quantity of DHA in the entire body (Vancassel, 2004). This deficiency prevails due to the genetic and dietary situation of infants weaned during the ice age.

In the last 10 years or so, studies have increasingly highlighted the relationships between DHA deficiency and certain neuropathologies in children, like hyperactivity, learning difficulties (Milte et al., 2012), mental retardation (Neggers et al., 2009), epilepsy, (Emory University Health Sciences Center, 2004) and autism (Bent et al., 2009). For Neanderthal man, this deficiency probably caused high levels of infant mortality and negative demographics during this glacial period. This situation was aggravated by Neanderthal man's lower fertility levels for the following reasons. The Leukemia inhibitory factor (LIF) is an essential cytokine for the implantation of the embryo in the uterine endometrium during the blastocyst stage (Stewart et al., 1992). Two molecules play a role in the regulation of LIF expression: estradiol concentration, via estrogen receptor $\alpha$ (Chen et al., 2000) and the activation of the tumor suppressor protein $\mathrm{p} 53$ (TP53 gene) (Paskulin et al., 2012). There are several SNPs for the TP53 gene in humans. The most commonly studied variant is that of codon 72 (arginine/proline). The arginine allele produces twice as much uterine LIF than the proline allele during implantation (Kang et al., 2009). But Arg72 is only found in Homosapiens while Pro72 is found in Homo neanderthalensis and chimpanzees (Feng et al., 2011). This genetic fragility in Neanderthal man's fertility was aggravated by the DHA deficiency (PPAR $\gamma$-RXR ligand) during this period. Indeed, PPARy-RXR (i) blocks the transcription of the $S H B G$ gene, reduces SHBG concentration, increases the quantity of free estradiol (Selva and Hammond, 2009) and (ii) induces the expression of P53 (Bonofiglio et al., 2006).

\subsection{Disappearance or adaptation}

Contrary to Homo sapiens, Neanderthal man did not have the conditions to adapt because the gap was too great to reach a new physiological equilibrium in the brain, while preserving its fertility. Physiological priorities on the use of DHA were established during periods of scarcity. The necessary and indispensable conditions for this adaptation apparently went well beyond the genetic elasticity in the glacial ecosystem. Around 30000 years ago, certain concentrations of subjects can be found in coastal regions around the Mediterranean, in Portugal (Figueira Brava) (Pais and Legoinha, 2000) and at the Vanguard and Gorham Grottos near Gibraltar in Spain, where the last individuals survived until 28000 years ago (Finlayson et al., 2006). The remains of aquatic products (mollusks, fish, and marine mammals) have been found in both these sites (Callapez, 2000; Stringer et al., 2008). However, the coastline at the time was different to modern-day Europe. Due to the cooler climate, which caused glaciation, sea levels were much lower ( 40 to $70 \mathrm{~m}$ ), so coastline sites occupied by Neanderthal man are now submerged and inaccessible (Bicho and Haws, 2008). In any case, these remains of DHA-rich marine animals show that these final groups of Neanderthals, living near a 


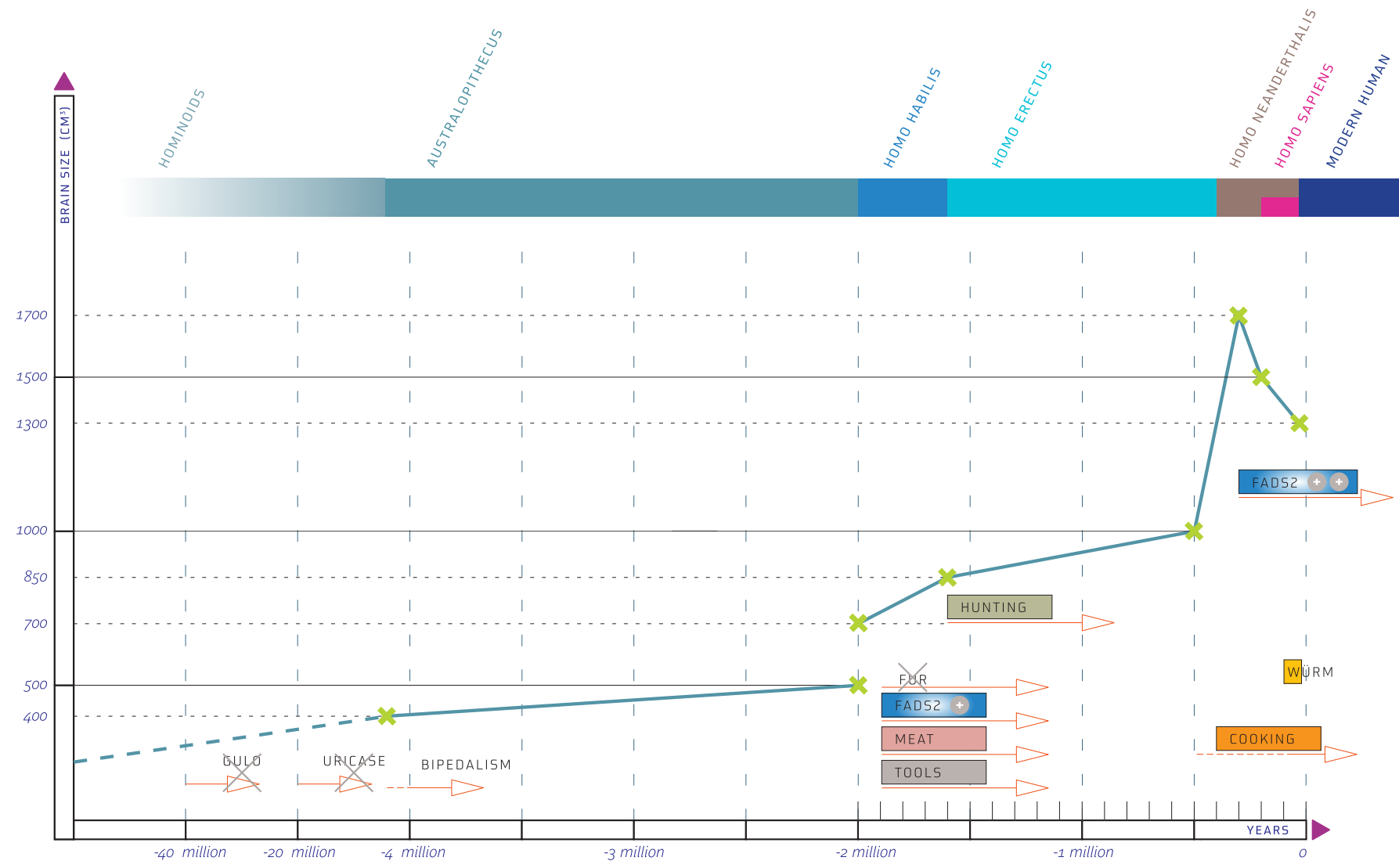

Fig 2. Evolution of the human brain size.

source of water, were able to survive temporarily thanks to their omega-3 fatty acid intake, and DHA in particular (Brenna and Diau, 2007).

Homo sapiens had a skull size of $1500 \mathrm{~cm}^{3}$ on average and the most DHA-productive haplotype of the FADS cluster (Green et al., 2010). With the reduction of plant-based sources of ALA, during a slightly milder period - the mid-Würmian period - selection pressure between DHA requirements (skull size) and DHA and ALA resources allowed subjects with a brain roughly $10 \%$ smaller $\left(1300-1400 \mathrm{~cm}^{3}\right.$-the size of the modern human brain) to survive. This evolution took place around 30000 years ago (Balzeau et al., 2013). This skull size, its cognitive capacity and its exogenous and endogenous DHA supply, enabled a stable physiological equilibrium in this ecosystem for a certain type of polymorphism of the FADS2 gene. Homosapiens enjoyed genetic and environmental conditions that enabled it to adapt to and face the final, harsher ice age while preserving its fertility levels.

These two species of the Homo genus show the consequences of a triggering factor - the Würm glaciation - on a physiological equilibrium stretched to the limits of its cognitive capacities. This elasticity was maintained by an ALA- and DHA-rich diet, but made fragile by the polymorphism of the FADS2 gene. This extreme was selected for Homo sapiens individuals that could find a new balance with lower ALA and DHA requirements. But it led to the progressive disappearance of Homo neanderthalensis under genetic pressure (FADS2 and TP53 in particular) and a DHA deficiency that impacted the brain and fertility. These elements form the basis of a new hypothesis on the reasons for the progressive extinction of Homoneanderthalensis, at the crossroads of genetics and nutrition.

\section{Conclusion}

The development of brain size, and cognitive capital more generally, of hominids until the emergence of Homo sapiens is due to interactive, iterative, and integrative coevolution, allowing positive selection. Although this depends on many different factors, three categories stand out: gene mutations, appropriate food resources, and permanent cognitive and behavioral stimulation (Fig. 2).

Because the brain uses a lot of energy, the virtuous circle of its evolution occurs through energy and antioxidant optimization with respect to the requirements created by various stimuli. If equilibrium is found, selection is viable in an ecosystem. When this balance is structurally broken in the long term, the individual disappears. This optimization concerns the entire body, on two levels: reduced energy consumption in certain physiological functions and increased availability of glucose for the brain, in particular, with the simultaneous increase in antioxidant defenses.

Australopithecus benefited both from the inactivation of the GULO and uricase genes and from bipedalism. From then onwards, the cognitive capital of the Homo genus was able to develop advantageously. This evolution is at the conjunction of two essential factors. Firstly, a triggering factor: gradual climate change with major repercussions on the African 
subtropical ecosystem, which had direct consequences on the quality and diversity of food resources. Homo became a regular consumer of meat in addition to plants and insects. Secondly, a stimulating factor: mutations in the FADS2 gene; a key enzyme in the synthesis of DHA and sapienic acid. This gene is very important for the adaptation of the Homo genus to its different types of diet, correlatively to its evolution, in particular in ecosystems with limited access to ALA and DHA. It has the undeniable advantage of synthesis and can in part explain positive selection.

With the advent of cooking and new, more productive mutations of FADS2, the brain reached its maximum size in Homo neanderthalensis, in a food ecosystem with favorable quantities of $\alpha$-Linolenic acid and DHA in particular. However, the Würm glaciation upset this equilibrium, revealing its fragility. Homo sapiens, with the advantage of new variants of the FADS2 gene, was able to adapt to this harsh environment, whereas Neanderthal man was unable to do so and became extinct.

At the end of the ice age, Homo sapiens adapted to variations in climate and diet imposed by the ecosystem. This slow and progressive evolution took around 2 million years. The last deglaciation, which began around 20000 years ago, led to a very favorable climate for our species. In relatively stationary conditions, favorable to the development of crop and livestock farming, humans were able to develop and multiply. Nowadays, modern humans must adapt to the ecosystem that they have created and imposed on themselves over more than a century, since the second industrial revolution, whose evolution is accelerating rapidly. Will they manage?

\section{References}

Agus DB, Gambhir SS, Pardridge WM, et al. 1997. Vitamin C crosses the blood-brain barrier in the oxidized form through the glucose transporters. J Clin Inves 100(11): 2842-2848.

Ameur A, Enroth S, Johansson A, et al. 2012. Genetic adaptation of fatty-acid metabolism: a human-specific Haplotype increasing the biosynthesis of long-chain omega-3 and omega- 6 fatty acids. $\mathrm{Am}$ J Hum Genet 90(5): 809-820.

Balzeau A, Grimaud-Hervé D, Détroit F, Holloway RL, Combès B, Prima S. 2013. First description of the Cro-Magnon 1 endocast and study of brain variation and evolution in anatomically modern Homo sapiens. Bull Mém Soc Anthropol Paris 25(1): 1-18.

Bent S, Bertoglio K, Hendren RL. 2009. Omega-3 fatty acids for Autistic Spectrum Disorder: a systematic review. J Autism Dev Disord 39(8): 1145-1154.

Berger L, Gerson CD, Yu TF. 1977. The effect of ascorbic acid on uric acid excretion with a commentary on the renal handling of ascorbic acid. Am J Med 62: 71-76.

Beyer RE. 1994. The role of ascorbate in antioxidant protection of biomembranes: interaction with vitamin $\mathrm{E}$ and coenzyme Q. $J$ Bioenerg Biomembr 26(4): 349-358.

Bicho N, Haws J. 2008. At the land's end: marine resources and the importance of fluctuations in the coastline in the prehistoric huntergatherer economy of Portugal. Quat Sci Rev 27(23-24): 2166-2175.

Bilsborough S, Mann N. 2006. A review of issues of dietary protein intake in humans. Int J Sport Nutr Exerc Metab 16(2): 129-152.

Blumenschine RJ. 1986. Carcass consumption sequences and the archaeological distinction of scavenging and hunting. J Hum Evol 15: 639-659.
Blumenschine RJ, Cavallo JA. 1992. Scavenging and human evolution. Sci Am 267: 90-96.

Bocquet-Appel JP, Demars PY, Noiret L, Dobrowsky D. 2005. Estimates of Upper Palaeolithic meta-population size in Europe from archaeological data. J Archaeol Sci 32: 1656-1668.

Bonofiglio D, Aquila S, Catalano S, et al. 2006. Peroxisome proliferator-activated receptor-gamma activates p53 gene promoter binding to the nuclear factor-kappaB sequence in human MCF7 breast cancer cells. Mol Endocrinol 20(12): 3083-3092.

Börjesson SI, Elinder F. 2008. Structure, function, and modification of the voltage sensor in voltage-gated ion channels. Cell Biochem Biophys 52(3): 149-174.

Bourgeois JP. 2005. Brain synaptogenesis and epigenesis. Med Sci 1(4): 428-433.

Bourre JM. 2006. Effects of nutrients (in food) on the structure and function of the nervous system: update on dietary requirements for brain. Part 1: micronutrients. J Nutr Health Aging 10: $377-$ 385.

Boverhof DR, Burgoon LD, Williams KJ, Zacharewski TR. 2008. Inhibition of estrogen-mediated uterine gene expression responses by dioxin. Mol Pharmacol 73(1): 82-93.

Bradbury J. 2005. Molecular insights into human brain evolution. PLoS Biol 3(3): e50.

Brandes N, Schmitt S, Jakob U. 2009. Thiol-based Redox switches in Eukaryotic proteins. Antioxid Redox Signal 11(5): 997-1014.

Brenna JT, Diau GY. 2007. The influence of dietary docosahexaenoic acid and arachidonic acid on central nervous system polyunsaturated fatty acid composition. Prostaglandins Leukot Essent Fatty Acids 77(5-6): 247-250.

Brenna JT, Varamini B, Jensen RG, Diersen-Schade DA, Boettcher JA, Arterburn LM. 2007. Docosahexaenoic and arachidonic acid concentrations in human breast milk worldwide. Am J Clin Nutr 85(6): 1457-1464.

Broadhurst CL, Cunnane SC, Crawford MA. 1998. Rift Valley lake fish and shellfish provided brain-specific nutrition for early Homo. Br J Nutr 79(1): 3-21.

Broadhurst CL, Wang Y, Crawford MA, Cunnane SC, Parkington JE, Schmidt WF. 2002. Brain-specific lipids from marine, lacustrine, or terrestrial food resources: potential impact on early African Homo sapiens. Comp Biochem Physiol B Biochem Mol Biol 131 (4): 653-673.

Brown KS, Marean CW, Herries A, et al. 2009. Fire as an engineering tool of early modern humans. Science 325(5942): 859-862.

Callapez P. 2000. Upper Pleistocene marine invertebrates from Gruta da Figueia Brava (Arrábida, Portugal). Memórias da Academia das Ciencias de Lisboa, Classe de Ciências XXVIII: 83-103.

Capper EA, Marshall LA. 2001. Mammalian phospholipases A(2): mediators of inflammation, proliferation and apoptosis. Prog Lipid Res 40(3): 167-197.

Carmody RN, Wrangham RW. 2009. The energetic significance of cooking. J Hum Evol 57(4): 379-391.

Carpenter KJ. 1994. Protein and energy: a study of changing ideas in nutrition. Cambridge: Cambridge University Press.

Chen JR, Cheng JG, Shatzer T, Sewell L, Hernandez L, Stewart CL. 2000. Leukemia inhibitory factor can substitute for nidatory estrogen and is essential to inducing a receptive uterus for implantation but is not essential for subsequent embryogenesis. Endocrinology 141(12): 4365-4372.

Cho HP, Nakamura MT, Clarke SD. 1999. Cloning, expression, and nutritional regulation of the mammalian Delta-6 desaturase. $J$ Biol Chem 274(1): 471-477.

Cho HK, Gao X, Curhan G. 2009. Vitamin C intake and the risk of gout in men: a prospective study. Arch Intern Med 169: 502-507. 
Conklin-Brittain NL, Wrangham RW, Smith CC. 1998. Relating Chimpanzee Diets to Potential Australopithecine Diets, 14th International Congress of Anthropological and Ethnological Sciences. Williamsburg, Virginia (USA).

Cordain L, Watkins BA, Mann NJ. 2001. Fatty acid composition and energy density of foods available to African hominids. Evolutionary implications for human brain development. World Rev Nutr Diet 90: 144-161.

Cunningham SK, Loughlin T, Culliton M, McKenna TJ. 1984. Plasma sex hormone-binding globulin levels decrease during the second decade of life irrespective of pubertal status. J Clin Endocrinol Metab 58(5): 915-918.

Dahl-Jensen D, Albert MR, Aldahan A, et al. 2013. Eemian interglacial reconstructed from a Greenland folded ice core. Nature 493(7433): 489-494.

Davies KJ, Sevanian A, Muakkassah-Kelly SF, Hochstein P. 1986. Uric acid-iron ion complexes. A new aspect of the antioxidant functions of uric acid. Biochem J 235(3): 747-754.

Defoliart GR. 1991. Insect fatty acids: similar to those of poultry and fish in their degree of unsaturation, but higher in the polyunsaturates. Food Insects Newsl 4(1): 1-8.

Delplanque B. 2017. Acides gras oméga-3 : de l'acide $\alpha$-linolénique (ALA) à l'acide docosahexaénoïque (DHA). Lipid Nutri+ 3.

Demars PY. 2008. Hunter's paleogeography of Europe during the Upper Paleolithic: site repartition and specialization. L'Anthropologie 112(2): 157-167.

Drake DR, Brogden KA, Dawson DV, Wertz PW. 2008. Thematic review series: skin lipids. Antimicrobial lipids at the skin surface. $J$ Lipid Res 49: 4-11.

Drouin G, Godin JR, Pagé B. 2011. The genetics of vitamin C loss in vertebrates. Current Genom 12(5): 371-378.

Dutton A, Lambeck K. 2012. Ice volume and sea level during the last interglacial. Science 337(6091): 216-219.

Edmond J, Robbins RA, Bergstrom JD, Cole RA, de Vellis J. 1987. Capacity for substrate utilization in oxidative metabolism by neurons, astrocytes, and oligodendrocytes from developing brain in primary culture. Neurosci Res 18(4): 551-561.

EFSA. 2010. Scientific Opinion on Dietary Reference Values for fats, including saturated fatty acids, polyunsaturated fatty acids, monounsaturated fatty acids, trans fatty acids, and cholesterol. EFSA $J$ 8(3): 1461.

Emory University Health Sciences Center. 2004. Patients with uncontrolled epilepsy have low levels of fatty acids. ScienceDaily.

Ernest MJ, Kim KH. 1974. Regulation of rat liver glycogen synthetase D. Role of glucose 6-phosphate and enzyme sulfhydryl groups in activity and glycogen binding. J Biol Chem 249: 5011-5018.

Feng Z, Zhang C, Kang HJ, et al. 2011. Regulation of female reproduction by $\mathrm{p} 53$ and its family members. FASEB $J$ 25(7): 2245-2255.

Finlayson C, Pacheco FG, Rodríguez-Vidal J, et al. 2006. Late survival of Neanderthals at the southernmost extreme of Europe. Nature 443(7113): 850-853.

Fuster JM. 2002. Frontal lobe and cognitive development. J Neurocytol 31(3-5): 373-385.

Ge L, Gordon JS, Hsuan C, Stenn K, Prouty SM. 2003. Identification of the delta- 6 desaturase of human sebaceous glands: expression and enzyme activity. $J$ Invest Dermatol 120(5): 707-714.

Glaser C, Lattka E, Rzehak P, Steer C, Koletzko C. 2011. Genetic variation in polyunsaturated fatty acid metabolism and its potential relevance for human development and health. Matern Child Nutr Suppl 2: 27-40.

Green RE, Krause J, Briggs AW, et al. 2010. A draft sequence of the Neandertal genome. Science 328: 710-722.
Guil-Guerrero JL, Rincón-Cervera MA, Venegas-Venegas CE, Ramos-Bueno RP, Suárez-Medina MD. 2013. Highly bioavailable $\alpha$-linolenic acid from the subcutaneous fat of the Palaeolithic relict "Galician horse". Int Food Res J 20: 3249-3258.

Guil-Guerrero JL, Tikhonov A, Rodríguez-García I, Protopopov A, Grigoriev S, Ramos-Bueno RP. 2014. The fat from frozen mammals reveals sources of essential fatty acids suitable for Palaeolithic and Neolithic humans. Schunck W-H, ed. PLOS ONE 9(1): e84480

Hardy BL. 2010. Climatic variability and plant food distribution in Pleistocene Europe: implications for Neanderthal diet and subsistence. Quat Sci Rev 29(5-6): 662-679.

Harrison FE, May JM. 2009. Vitamin C function in the brain: vital role of the ascorbate transporter SVCT2. Free Radic Biol Med 46 (6): 719-730.

Henry AG, Brooks AS, Piperno DR. 2011. Microfossils in calculus demonstrate consumption of plants and cooked foods in Neanderthal diets (Shanidar II, Iraq; Spy I and II, Belgium). Proc Nat Acad Sci USA 108(2): 486-491.

Holliday M. 1971. Metabolic rate and organ size during growth from infancy to maturity and during late gestation and early infancy. Pediatrics 47: 169-172.

Innis SM, Dyer RA. 2002. Brain astrocyte synthesis of docosahexaenoic acid from n-3 fatty acids is limited at the elongation of docosapentaenoic acid. J Lipid Res 43(9): 1529-1536.

Jerison H. 1973. Evolution of the human brain and intelligence. London: Academic Press.

Johnson RJ, Gaucher EA, Sautin YY, Henderson GN, Angerhofer AJ, Benner SA. 2008. The planetary biology of acid L-ascorbic and uric acid and their relationship with the epidemic of obesity and cardiovascular disease. Med Hypotheses 71(1): 22-31.

Joost H, Thorens B. 2001. The extended GLUT-family of sugar/ polyol transport facilitators: nomenclature, sequence characteristics, and potential function of its novel members. $\mathrm{Mol} \mathrm{Membr}$ Biol 18(4): 247-256.

Jump DB, 2002. The biochemistry of n-3 polyunsaturated fatty acids. J Biol Chem 277: 8755-8758.

Kang HJ, Feng Z, Sun Y, et al. 2009. Single-nucleotide polymorphisms in the p53 pathway regulate fertility in humans. Proc Nal Acad Sci USA 106(24): 9761-9766.

Katsuta Y, Iida T, Inomata S, Denda M. 2005. Unsaturated fatty acids induce calcium influx into keratinocytes and cause abnormal differentiation of epidermis. J Invest Dermatol 124(5): 10081013.

Katzman JJ. 1993. Education and the prevalence of dementia and Alzheimer's Disease. Neurology 43: 13-20.

Kay RF. 1985. Dental evidence for the diet of Australopithecus. Ann Rev Anthropol 14: 315-341.

Kratzer JT, Lanaspa MA, Murphy MN, et al. 2014. Evolutionary history and metabolic insights of ancient mammalian uricases. Proc Nat Acad Sci USA 111: 3763-3768.

Kuipers RS, Luxwolda MF, Dijck-Brouwer DA, et al. 2010. Estimated macronutrient and fatty acid intakes from an East African Paleolithic diet. Br J Nutr 104(11): 1666-1687.

Lattka E, Illig T, Koletzko B, Heinrich J. 2010. Genetic variants of the FADS1 FADS2 gene cluster as related to essential fatty acid metabolism. Curr Opin Lipidol 21 (1): 64-69.

Leonard WR, Robertson ML. 1994. Evolutionary perspectives on human nutrition: the influence of brain and body size on diet and metabolism. Am J Hum Bio 6: 77-88.

Leonard WR, Robertson ML. 1997. Comparative primate energetics and hominid evolution. Am J Phys Anthropol 102(2): 265-281. 
Leonard WR, Snodgrass JJ, Robertson ML. 2010. Evolutionary perspectives on fat ingestion and metabolism in humans. In: Montmayeur JP, le Coutre J, eds. Fat detection: taste, texture, and post ingestive effects. Boca Raton (FL): CRC Press/Taylor \& Francis, Chapter 1 .

de Lumley H, de Lumley MA. 1973. Pre-Neanderthal Human remains from Arago Cave in southeastern France. Yearb Phys Anthropol 17: $162-168$.

de Lumley H. 2006. Il y a 400000 ans : la domestication du feu, un formidable moteur d'hominisation. $C R$ Palevol 5: 149-154.

Mac Innes KJ, Brown KA, Hunger NI, Simpson ER. 2012. Regulation of LKB1 expression by sex hormones in adipocytes. Int J Obes 36 (7): 982-985.

Majou D. 2015. Alzheimer's disease: origins, mechanisms, people at risk and prevention by DHA (omega-3 fatty acid). Paris (France): Actia Editions.

Makrides M, Neumann MA, Gibson RA. 1996. Effect of maternal docosahexaenoic acid (DHA) supplementation on breast milk composition. Eur J Clin Nutr 50(6): 352-357.

Markesbery WR. 1999. The role of oxidative stress in Alzheimer disease. Arch Neurol 56: 1449-1452.

Matsuzaka T, Shimano H, Yahagi N, et al. 2002. Dual regulation of mouse Delta(5)- and Delta(6)-desaturase gene expression by SREBP-1 and PPARalpha. J Lipid Res 43(1): 107-114.

de Menocal PB. 2004. African climate change and faunal evolution during the Pliocene-Pleistocene. Earth Plan Sci Lett 220(1-2): 3-24.

Milte CM, Parletta N, Buckley JD, Coates AM, Young RM, Howe PR. 2012. Eicosapentaenoic and docosahexaenoic acids, cognition, and behavior in children with attention-deficit/hyperactivity disorder: a randomized controlled trial. Nutrition 28(6): 670-677.

Milton K. 2003. The critical role played by animal source foods in human (Homo) evolution. J Nutr 133(11 Suppl 2): 3886S-3892S.

Mink JW, Blumenschine RJ, Adams DB. 1981. Ratio of central nervous system to body metabolism in vertebrates: its constancy and functional basis. Am J Physiol 241(3): R203-R212.

Moltó-Puigmarti C, Plat J, Mensink RP, et al. 2010. FADS1 FADS2 gene variants modify the association between fish intake and the docosahexaenoic acid proportions in human milk. Am J Clin Nutr 91: $1368-1376$

Nakamura MT, Nara TY. 2004. Structure, function, and dietary regulation of delta6, delta5, and delta9 desaturases. Ann Rev Nutr 24: $345-376$.

Nandi A, Mukhopadhyay CK, Ghosh MK, Chattopadhyay DJ, Chatterjee IB. 1997. Evolutionary significance of vitamin C biosynthesis in terrestrial vertebrates. Free Radic Biol Med 22(6): 1047-1054.

Neggers YH, Kim EK, Song JM, Chung EJ, Um YS, Park T. 2009. Mental retardation is associated with plasma omega-3 fatty acid levels and the omega-3/omega-6 ratio in children. Asia Pac J Clin Nutr 18(1): 22-28.

Ohta Y, Nishikimi M. 1999. Random nucleotide substitutions in primate nonfunctional gene for L-gulono-gamma-lactone oxidase, the missing enzyme in L-ascorbic acid biosynthesis. Biochim Biophys Acta 1472(1-2): 408-411.

O'Neill CM, Minihane AM. 2017. The impact of fatty acid desaturase genotype on fatty acid status and cardiovascular health in adults. Proc Nutr Soc 76(1): 64-75.

Pais J, Legoinha P. 2000. Gruta da Figueira Brava (Arrábida): geological setting. Memórias da Academia das Ciências de Lisboa, Classe de Ciências, XXXVIII: 69-91.

Paskulin DD, Paixao-Cortes VR, Hainaut P, Bortolini MC, AshtonProlla P. 2012. The TP53 fertility network. Genet Mol Biol 35(4 (suppl)): 939-946.
Perry GH, Dominy NJ, Claw KG, et al. 2007. Diet and the evolution of human amylase gene copy number variation. Nat Genet 39(10): $1256-1260$.

Perry GH, Kistler L, Kelaita MA, Sams AJ. 2015. Insights into hominin phenotypic and dietary evolution from ancient DNA sequence data. J Hum Evol 79: 55-63.

Picardo M, Ottaviani M, Camera E, Mastrofrancesco A. 2009. Sebaceous gland lipids. Dermato-endocrinology 1(2): 68-71.

Plummer T. 2004. Flaked stones and old bones: biological and cultural evolution at the dawn of technology. Am J Phys Anthropol Suppl 39: 118-164.

Pobiner BL, Rogers MJ, Monahan CM, Harris JW. 2008. New evidence for hominin carcass processing strategies at $1.5 \mathrm{Ma}$, Koobi Fora, Kenya. J Hum Evol 55(1): 103-130.

Pontzer H, Raichlen DA, Sockol MD. 2009. The metabolic cost of walking in humans, chimpanzees, and early hominins. J Hum Evol 56(1): 43-54.

Porter AMW. 1993. Sweat and thermoregulation in hominids. Comments prompted by the publications of PE Wheeler 1984 1993. J Hum Evol 25: 417-423.

Porter AMW. 2001. Why do we have apocrine and sebaceous glands? $J$ R Soc Med 94(5): 236-237.

Prouty SM, Pappas A. 2015. Sapienic acid: species-specific fatty acid metabolism of the human sebaceous gland. In: Pappas A, ed. Lipids and skin health. New York: Springer International Publishing, pp. 139-157.

Reed BC, Cefalu C, Bellaire BH, et al. 2005. GLUT1CBP(TIP2/ GIPC1) interactions with GLUT1 and myosin VI: evidence supporting an adapter function for GLUT1CBP. Mol Biol Cell 16(9): 4183-4201.

Reiner WB, Petzinger C, Power ML, Hyeroba D, Rothman JM. 2014. Fatty acids in mountain gorilla diets: implications for primate nutrition and health. Am J Primatol 76(3): 281-238.

Robert A, Mfilinge P, Limbu SM, Mwita CJ. 2014. Fatty Acid composition and levels of selected polyunsaturated Fatty acids in four commercial important freshwater fish species from lake Victoria, Tanzania. J Lipids 2014: 712134.

Roebroeks W, Villa P. 2011. On the earliest evidence for habitual use of fire in Europe. Proc Nal Acad Sci USA 108(13): 52095214.

Rogers NH, Witczak CA, Hirshman MF, Goodyear LJ, Greenberg AS. 2009. Estradiol stimulates Akt, AMP-activated protein kinase (AMPK) and TBC1D1/4, but not glucose uptake in rat soleus. Biochem Biophys Res Commun 382(4): 646-650.

Rumsey SC, Kwon O, Xu GW, Burant CF, Simpson I, Levine M. 1997. Glucose transporter isoforms GLUT1 and GLUT3 transport dehydroascorbic acid. J Biol Chem 272(30): 18982-18989.

Rzehak P, Heinrich J, Klopp N, et al. 2009. Evidence for an association between genetic variants of the fatty acid desaturase 1 fatty acid desaturase 2 (FADS1 FADS2) gene cluster and the fatty acid composition of erythrocyte membranes. Br J Nutr 101(1): 20-26.

Sampels S. 2005. Fatty acids and antioxidants in Reindeer and Red Deer. Emphasis on animal nutrition and consequent meat quality. Doctoral thesis, Swedish University of Agricultural Sciences, Upsala.

Sanders TA, Reddy S. 1992. The influence of a vegetarian diet on the fatty acid composition of human milk and the essential fatty acid status of the infant. $J$ Pediatr 120(4 Pt 2): S71-S77.

Schaeffer L, Gohlke H, Müller M, et al. 2006. Common genetic variants of the FADS1 FADS2 gene cluster and their reconstructed haplotypes are associated with the fatty acid composition in phospholipids. Hum Mol Genet 15(11): 1745-1756. 
Selva DM, Hammond GL. 2009. Peroxisome-proliferator receptor gamma represses hepatic sex hormone-binding globulin expression. Endocrinology 150(5): 2183-2189.

Sevanian A, Davies KJ, Hochstein P. 1985. Conservation of vitamin C by uric acid in blood. J Free Rad Biol Med 1: 117-124.

Shi J, Simpkins JW. 1997. 17 beta-Estradiol modulation of glucose transporter 1 expression in blood-brain barrier. Am J Physiol 272 (6 Pt 1): E1016-E1022.

Simopoulos AP. 2006. Evolutionary aspects of diet, the omega-6/ omega-3 ratio and genetic variation: nutritional implications for chronic diseases. Biomed Pharmacother 60(9): 502-507.

Sinclair AJ, Crawford MA. 1972. The incorporation of linolenic and docosahexaenoic acid into liver and brain lipids of developing rats. FEBS Lett 26: 127-129.

Smith CD, Carney JM, Starke-Reed PE, et al. 1991. Excess brain protein oxidation and enzyme dysfunction in normal aging and in Alzheimer disease. Proc Nat Acad Sci USA 88(23): 10540-10543.

Sockol MD, Raichlen DA, Pontzer H. 2007. Chimpanzee locomotor energetics and the origin of human bipedalism. Proc Nat Acad Sci USA 104(30): 12265-12269.

Södergard R, Bäckström T, Shanbhag V, Carstensen H. 1982. Calculation of free and bound fractions of testosterone and estradiol-17 beta to human plasma proteins at body temperature. $J$ Steroid Biochem 16(6): 801-810.

Stewart CL, Kaspar P, Brunet LJ, et al. 1992. Blastocyst implantation depends on maternal expression of leukaemia inhibitory factor. Nature 359(6390): 76-79.

Stoffel W, Holz B, Jenke B, et al. 2008. Delta6-desaturase (FADS2) deficiency unveils the role of omega3- and omega6-polyunsaturated fatty acids. $E M B O J$ 27(17): 2281-2292.

Stringer CB, Finlayson JC, Barton RNE, et al. 2008. Neanderthal exploitation of marine mammals in Gibraltar. PNAS 105(38): 14319-14324.

Tang C, Cho HP, Nakamura MT, Clarke SD. 2003. Regulation of human delta- 6 desaturase gene transcription: identification of a functional direct repeat-1 element. J Lipid Res 44(4): 686-695.

Tosi F, Sartori F, Guarini P, et al. 2014. Delta-5 and delta-6 desaturases: crucial enzymes in polyunsaturated fatty acid-related pathways with pleiotropic influences in health and disease. $A d v$ Exp Med Biol 824: 61-81.

Van Kolfschoten T. 2000. The Eemian mammal fauna of Central Europe. Netherlands J Geosci 79(2-3): 269-281.

Vancassel S. 2004. Oméga 3 et neurotransmission cérébrale. $O C L$ 11(1): 58-65.

Voss A, Reinhart M, Sankarappa S, Sprecher H. 1991. The metabolism of 7,10,13,16,19-docosapentaenoic acid to $4,7,10,13,16,19$-docosahexaenoic acid in rat liver is independent of a 4-desaturase. J Biol Chem 266(30): 19995-20000.

Wainwright PE. 1992. Do essential fatty acids play a role in brain and behavioral development? Neurosci Behav Rev 16: 193-205.

Walter RC, Buffler RT, Bruggemann JH, Guillaume MM, et al. 2000. Early human occupation of the Red Sea coast of Eritrea during the last interglacial. Nature 405(6782): 65-69.

Wang DY, Fulthorpe R, Liss SN, Edwards EA. 2004. Identification of estrogen-responsive genes by complementary deoxyribonucleic acid microarray and characterization of a novel early estrogeninduced gene: EEIG1. Mol Endocrinol 18(2): 402-411.

Williams G, Crawford MA. 1987. Comparison of the fatty acid component in structural lipids from dolphins, zebra and giraffe: possible evolutionary implications. J Zool Lond 213: 673-684.

Williams MF. 2002. Primate encephalization and intelligence. Med Hypotheses 58(4): 284-290.

Womeni HM, Linder M, Tiencheu B, et al. 2009. Oils of insects and larvae consumed in Africa: potential sources of polyunsaturated fatty acids. $O C L$ 16: 230-235.

Wu XW, Lee CC, Muzny DM, Caskey CT. 1989. Urate oxidase: primary structure and evolutionary implications. Proc Nat Acad Sci USA 86(23): 9412-9416.

Wu XW, Muzny DM, Lee CC, Caskey CT. 1992. Two independent mutational events in the loss of Urate Oxidase during Hominoid evolution. J Mol Evol 34: 78-84.

Xie L, Innis SM. 2008. Genetic variants of the FADS1 FADS2 gene cluster are associated with altered (n-6) and (n-3) essential fatty acids in plasma and erythrocyte phospholipids in women during pregnancy and in breast milk during lactation. J Nutr 138(11): $2222-2228$

Cite this article as: Majou D. 2018. Evolution of the Human Brain: the key roles of DHA (omega-3 fatty acid) and $\triangle 6$-desaturase gene. $O C L$ 25(4): A401. 